\title{
INSTITUTIONAL AND NON-INSTITUTIONAL CREDIT SUPPLY SERVICES TO FISHER WOMEN IN COASTAL FISHING COMMUNITIES OF SOUTH WESTERN NIGERIA: AN EMPIRICAL SURVEY
}

\author{
Omotoso F.O. and Daramola, A.G.
}

\begin{abstract}
Ondo State occupies a unique position due to her natural fisheries resources in South Western Nigeria. Fisheries play a positive role in the supply of delicious and high quality protein food for the people of the country. Credit is a powerful doorway to reduce poverty. It helps the poor to fight against poverty with their own efforts. Particularly, empowerment of women can help to alleviate poverty and mobilize natural resources. Women play an important role in the processing and trading of fish. However, they are limited in their marketing opportunities and access to credit. Moreover, arrangement of adequate finance at market rate may contribute significant role in the socio-economic development of coastal women fisher folk in the study areas. Again financial support system needs to be dynamic so that concerned women fisher folk can get the benefits of institutional credit facilities. The paper focuses on the institutional and non institutional credit services and with reference to the coastal women fisher folk of the fishing communities of Ilaje and Ese Odo Local Government areas of Ondo State. The data and information have been collected from 150 women fisher folk of five fishing villages through questionnaire. Women in the study area prefer the informal, non institutional credit sources than the formal, institutional source as the poor fisher-folk require collateral for this which in most cases was not available. From the study, adequate finance with more relax conditions will go a long way in alleviating poverty and improving socio-economic development of the rural coastal fisher women.
\end{abstract}

Keywords: credit services, fishing communities, sources of income, appropriate savings, and alternative credit systems.

\section{INTRODUCTION}

The significance of the fishery sub-sector in the Nation's economy can be viewed from two perspectives. Firstly, it is an important source of animal protein for a wider spectrum of the Nigerian populace. Based on the information in the Fourth National Development Plan (1980 - 85), 40\% of animal protein consumed by the average Nigerian comes from fish. Secondly, fisheries provide gainful employment opportunities for many Nigerians especially people in the coastal, riverine and lake areas of the country. According to Mogbojuri (1987), about two million depend directly or indirectly on artisanal fishery alone in Nigeria thereby empowering them. Empowerment is a process, which enables individuals or groups to change balance of power through exchange of experience, expertise, technology and know-how as well as diffusing innovative technique for strengthening the self-reliance. Considering the role of women in the agricultural set up of the Nation, it has been found that women do the bulk of the job both in the farming sector and in the fishing communities. (Adekanye, 1989, Altieri 1993). In many developing countries, particularly Nigeria, the involvement of women in agricultural production has been restricted to family labour, which in most cases is un-remunerated. In some cases, where women are involved in agricultural production, like fishing, lack of technical know-how, low financial power and other resources have severely constrained their efficiency, restrict their time and sap their energy from participating in other developmental programs (Omotoso, 2004). This has led to a decline in agricultural productivity, lack of supply of fish, creation of shortages to the market and the rise of the price of fish beyond the reach of the poor. At the same time, 
because of fish texture, and its highly digestible protein, the demand for fish continues to increase. This is further heightened by rapid increase in human population especially in the developing countries (of which Nigeria is one). Lightfoot (1990) reports that women activities should not be limited as often done in the past to "material" and "domestic" work such as sewing, knitting, food preparation, child care and house keeping. Women must be regarded seriously as producers and be given appropriate training, skills and encouragement to become more productive in order to contribute effectively to alleviating the poverty of rural families.

The purpose according to (Omotoso 2004) is not to remove them from the family to create independent women's power but to enhance their productivity in ways that add to their capacity and value within the rural community thus giving them more "bargaining power". One of the most important instruments for empowering women is to allow them equal access to and control over productive resources such as land, capital, technology, credit as well as marketing outlets, information, education, training etc without any discrimination (Omotoso 2004). In spite of forming 50 percent of the total population of the world, women do not own even one percent of the world property. Their role and contribution in industrialization has remained unaccounted and un-assessed. Their share in businesses and trades are very low. (Molyneux 2003), their contribution to leadership and management are much less. (Saleh, 1995) Time has come for women to come out of the drudgery of housework and give vent to the creativity and entrepreneurship. Again, from the dawn of the civilization, women played a complementary role to men to achieve all successes of mankind. Article 28(2) of the constitution of Nigeria emphasizes that women shall have equal rights in all spheres of state and of public life (Omotoso 2003). In Nigeria, it has been observed that women have remained outside the main stream of development activities.

Further, thousands of coastal women communities continued to suffer from poverty, illiteracy and unemployment. (Blowfield et al 1996). Also, women in fishing communities suffer from lack of access to fair credit sources. Institutional and financial access is further constrained as poor fisher-folk require larger loans (i. e. for the purchase of boats or fishing gear) and are considered a high risk by lending institutions,

including Government, banks, and NGOs (Kabeer 2003). As a consequence, they are more likely to depend on informal possibly exploitative credit sources, whereby fish-buyers also act as money lenders. Women play an important role in the processing and marketing of fish; however, they are limited in their marketing opportunities and access to credit. Loans tend to be given to male boat owners, who then have to sell an important part of their catch to the provider of the credit. (Kleih 2001).The interdependency between trade and finance means that women can only access credit through their husbands or other male relatives. Moreover, credit is a powerful doorway to reduce poverty. It helps the poor to fight against poverty with their own efforts. There is however lack of understanding of how the credit system in coastal fishing communities is organized. This research gap motivated the author to under take this study entitled "Institutional and non institutional credit services among women in Coastal Fishing Communities"

The objective of the research is to describe and understand the functioning of the credit system and the gender roles in coastal fisher communities and to develop recommendations for how to improve the livelihoods of poor participants in the fish commodity chain vis-à-vis those directly involve with the fish catch, processor, marketer and consumer. In the light of this main purpose, the specific purposes of the study will be as follows:

* Focus on credit and gender issues of coastal fishing communities;

* Identify constraints with these existing practices and point-out credit related problems of women fishers; 
* Identify appropriate savings and credit services and access to alternative credit systems and utilization of loans by women fisher-folk.

* Develop recommendations to be implemented by Government, NGO, and private sector and donor organizations.

\section{METHODOLOGY}

The study areas are Ilaje and Ese-odo Local Government areas of Ondo State. The two local Governments are bounded in the North by Ikale Local Government, to the South by the Atlantic Ocean, with a coastline of $80 \mathrm{Km}$ long. This makes Ondo State qualify as a maritime State and makes it rank among the highest fish producers in the country. About $80 \%$ of the Local Government area is covered with water, swamp and flood plains. Rivers largely intersect the area. A vegetation of white mangrove - Aucennia africana and Paspalum vaginatom, characterizes the coastline. Most of the flood plains of the coastal lagoon are covered by Typha, Avstralis and Eichornial crassipes (water hyacinth). The major means of transportation in the study area are motorized canoes, speedboats and paddled canoes. Most of the houses in the coastal and flood plain areas are built on elevated platforms above water level.

Primary data was used for this study which was collected using pre-tested and validated questionnaire prepared on the light of the objectives of the study. Through random selection, thirty (30) women were selected from five (5) different fishing villages making a total of one hundred and fifty (150) respondents in all. The samples are chosen to be typically representative of the population in terms of the characteristics of the study (small, medium and large scale investors). Collected data were analyzed through the use of various statistical tools like averages, percentages etc. The data were analyzed in order to make the study more informative and useful.

\section{RESULTS AND DISCUSSION \\ Personal Characteristics of the respondents}

According to the norm of the society, the roles of men and women in the society have tended to be quite different. But at present the nature of this role is gradually changing. Forward Looking Strategies' for the advancement of women is a culmination of general realization by the world community that attainment of any sustainable development activities can not be achieved without the full participation and integration of women in all spheres of life and development of an action plan to uplift the socio-economic position of women (Saleh, 1995). Thus an attempt has been made to get an idea about the personal characteristics of selected women fisher folk. Data in this regard have been shown in Table-I, 36\%, 26.67\%, 23.33\%, and $14 \%$ of the sample respondents are in the categories of married, divorced, widowed and single respectively.

\section{Table 1: Personal characteristics of respondents}

\begin{tabular}{lcc}
\hline Characteristics & Number of respondents & Frequency of percentage \\
\hline Single & 21 & 14.00 \\
Married & 54 & 36.00 \\
Divorced & 40 & 26.67 \\
Widow & 35 & 23.33 \\
\hline Total & 150 & 100 \\
\hline
\end{tabular}

The high percentage for married women is an indication that the women are permanent settlers in the area, all their activities revolve around the community and migration is a rare occurrence. It has been observed that these women fisher folk are involved in various types of 
income generating activities as shown in Table 11.

\section{Sources of Income of the respondents}

Though respondents earn from various sources, all sources are directly or indirectly related to fishing and other related activities. An attempt is made to find out the relative share of different sources of income. The survey results portrays that among the sample respondents $30 \%, 20 \%, 16.67 \% 13.3 \%, 12 \%$ and $8 \%$ earn from fish trading, net making and repairing, fish drying, basket fish packers, fish processing and others respectively (Table II). The implication of this flow chain is that it ensures sustainability of the business in the study area.

Table2: Sources of income of respondents

\begin{tabular}{lcc}
\hline Main Sources & Number of respondents & Frequency of percentage \\
\hline Fish trading & 45 & 30.00 \\
Net making and repairing & 30 & 20.00 \\
Fish drying & 25 & 16.67 \\
Making fish basket & 20 & 13.33 \\
Fish processing & 18 & 12.00 \\
Others & 12 & 8.00 \\
\hline Total & 150 & 100 \\
\hline
\end{tabular}

\section{Monthly Income of the respondents}

The survey results reveal that the range of income earned per month by the respondents ranged from N30, 000 and above at the highest to less than N5000 at the lowest. Again among the respondents the highest percentage of the respondents earned N10, 000 to N15, $000(28 \%)$ whereas the lowest percentage earned N30, 000 and above (10.67\%) (Table III).

Table 3: Monthly family income of the Women Headed Fisher folk

\begin{tabular}{|l|c|c|}
\hline Income $\left({ }^{\circ} 000 \mathrm{~N}\right)$ & Number of respondents & Frequency of percentage \\
\hline Less than 5 & 20 & 13.33 \\
\hline $5-10$ & 26 & 17.33 \\
\hline $10-15$ & 42 & 28.00 \\
\hline $15-20$ & 19 & 12.67 \\
\hline $25-30$ & 27 & 18.00 \\
\hline $30-$ and above & 16 & 10.67 \\
\hline Total & 150 & 100 \\
\hline
\end{tabular}

This is an indication that the capital level of the respondents is very low and the respondents have little marketable surplus taking the little left over to the market in exchange for cash. It is the surplus produced over and above what is required that is usually marketed. It is the income realized from such marketable surplus that can be re-invested in the business. It is the need to achieve a higher marketable surplus that encourages the women to take loan.

\section{Reasons for Taking Loan}

Women fisher folk demand basic needs i.e. food, housing, health care, sanitation, and education for maintaining their livelihood. The coastal fisher folk communities depend on only fish related works. It is their only sources of income. Again, the quantity of fish catching is declining day by day and women have limited trading opportunities. So they need credit for meeting their different types of requirements. In this context, it is important to know from the sample respondents about the reasons for taking credit. The survey data evidence that majority of the respondents $(18 \%)$ took loan to meet the losses 
caused by disasters, $17.33 \%$ for repayment of previous loan, $16 \%$ for daily recurring expenses (for food, medicine, education etc.), $14.66 \%$ for purchasing of bamboo in order to make bamboo-made fish baskets, $12.66 \%$ for purchasing yarn, $7.3 \%$ for marriage and dowry of their children and among the respondents (14\%) indicated that they did not take any loan from any sources (Table IV).

Table 4: Reasons for taking Loan

\begin{tabular}{|l|c|c|}
\hline Reasons for taking loan & Number of respondents & Frequency of percentage \\
\hline $\begin{array}{l}\text { Purchase of yarn for net } \\
\text { making }\end{array}$ & 19 & 12.66 \\
\hline Purchase of bamboo & 22 & 14.66 \\
\hline $\begin{array}{l}\text { Expenses on food, medicine } \\
\text { and education }\end{array}$ & 24 & 16.00 \\
\hline Marriage and dowry & 11 & 7.300 \\
\hline $\begin{array}{l}\text { Disasters (pollution, sea } \\
\text { incursion, water hyacinth } \\
\text { menace etc) }\end{array}$ & 27 & 18.00 \\
\hline Pay previous loan & 26 & 17.33 \\
\hline Not enjoyed any loan & 21 & 14.00 \\
\hline Total & 150 & 100 \\
\hline
\end{tabular}

\section{Sources of Credit}

The sample respondents take loan from two sources viz. institutional sources and noninstitutional sources. An attempt is made to find out the relative share and magnitude of institutional and non-institutional credits from the sample respondents in the study areas. The collected data in this regard shows that the sample respondents take lion share of their loans from non-institutional sources. The percentages of non-institutional sources are $56 \%$ where the contributions of institutional sources are only $44 \%$. A further query as to the sources of non-institutional loan, it was found that relatives ranked the highest $(21.33 \%)$ followed by friends $(2.7 \%)$, group contribution $(16.0 \%)$, cooperative societies $(9.4 \%)$, community lending $(6.7 \%)$ respectively (Table V). Among the institutional sources, the survey data show that Government assisted poverty eradication money lending scheme ranked the highest (17.33\%), NGO (5.33\%), Bank (7.33\%). (TableV).

\section{Table 5: Sources of Loan}

Sources

Relatives

Friends

Group contributions

Cooperative Societies

Community lending

NGO

Govt. lending scheme

Bank

Not enjoyed any loan

Total
Number of respondents Non institutional sources

$\begin{array}{cc}32 & 21.30 \\ 4 & 2.700 \\ 24 & 16.00 \\ 14 & 9.410 \\ 10 & 6.700 \\ \text { titutional sources } & \\ 8 & 5.33 \\ 26 & 17.33 \\ 11 & 7.30 \\ 21 & 14.0 \\ 150 & 100\end{array}$

Frequency of percentage

21.30

700

9.410

6.700

5.33

.30

100 


\section{Amount of Loan Taken from Various Sources}

Loan is taken for meeting the various purposes of sample respondents. The survey result portrays that among the sample respondents, the average loan taken was N20, 000 to N30, $000(36.67 \%)$ and the lowest was N40, 000 to N50, $000(6.67 \%)$. (Table VI). The rate of interest on loan money from the respondents was also examined.

Table 6: Amount of loan taken from various sources

\begin{tabular}{|c|c|c|}
\hline Loan amount $\left({ }^{\prime} 000 \mathrm{~N}\right)$ & Number of respondents & Frequency of percentage \\
\hline $5-10$ & 20 & 13.33 \\
\hline $10-20$ & 35 & 23.33 \\
\hline $20-30$ & 55 & 36.67 \\
\hline $30-40$ & 30 & 20.00 \\
\hline $40-50$ & 10 & 6.67 \\
\hline Total & 150 & 100 \\
\hline
\end{tabular}

\section{Rate of Interest}

The survey reveals that the range of rate of interest paid per month by the respondents varied from $15 \%$ at the highest with $20 \%$ of the respondent belonging to this group and to less than $2 \%$ at the lowest with $16 \%$ of the respondent in this group.

(Table VII). The preference of the respondents for non-institutional sources of loans was then examined.

Table 7: Rate of interest

\begin{tabular}{|l|c|c|}
\hline $\begin{array}{l}\text { Rate of interest paid/month. } \\
\%\end{array}$ & Number of respondents & Frequency of percentage \\
\hline Less than 2 & 16 & 10.67 \\
\hline $2.1-5$ & 30 & 20.00 \\
\hline $5.1-10.0$ & 40 & 26.67 \\
\hline $10.1-15.0$ & 30 & 20.00 \\
\hline $15.1-20.0$ & 20 & 13.33 \\
\hline 20 and above & 14 & 9.33 \\
\hline Total & 150 & 100 \\
\hline
\end{tabular}

\section{Reasons for Preferring Non-institutional Loans}

From the list of indicators for measuring preferences, the responses have corroborated that 'easy to access' ranked the highest (47.61\%), 'no collaterals' ranked the 2nd $(23.81 \%)$, 'no formalities are required' and "no stipulated repayment date followed. (11.90\%) respectively and then others $(4.76 \%)$ in order of magnitude (Table VIII). It has been observed that preference of market segment based on mainly two factors viz. easy access as well as no requirement of collateral.

Table 8: Reasons for preferring Non-institutional loan

\begin{tabular}{|c|c|c|}
\hline Reasons & Number of respondents & Frequency of percentage $*$ \\
\hline Easy to access & 40 & 47.61 \\
\hline No collaterals are required & 20 & 23.81 \\
\hline No formalities are required & 10 & 11.90 \\
\hline No stipulated repayment & 10 & 11.90 \\
\hline Others & 4 & 4.76 \\
\hline
\end{tabular}

* Multiple responses 


\section{Reasons for Disliking the Non-institutional Sources of Loan}

Most of non- institutional sources provide loan as well as dominating the trading of fish by the women fish traders in study areas. Due to this, poor women fishers virtually cannot play any role in trading of their fishes. The survey data show that the sample respondents' ranked 'exploited price of fish' as the 1st $(47.62 \%)$, 'difficult to calculate' ranked as the second $(29.76 \%)$ and 'creation of pressure' ranked as the 3rd (17.86\%) (Table IX). But unfavorable financial condition of women fishers compelled them to take the loan from non-institutional sources.

Table 9: Reasons for disliking the Non-institutional sources by the respondents

\begin{tabular}{|l|c|c|}
\hline Reasons & Number of respondents & Frequency of percentage $*$ \\
\hline Influenced price of fish & 40 & 47.62 \\
\hline Create pressure & 15 & 17.86 \\
\hline Difficult to calculate interest & 25 & 29.76 \\
\hline$\quad$ Others & 4 & 4.76 \\
\hline
\end{tabular}

* Multiple responses

\section{Reasons for Preferring Institutional Sources}

The survey data show the reasons for preferring institutional sources by the sample respondents. These are 'non-exploitation, 'low rate of interest', and 'possibility of getting exemption' for loan money and interest on it by the authority concerned. The respondents, opined that 'free from exploitation' ranked the highest (45.45\%), 'low rate of interest' ranked the 2 nd $(30.30 \%)$ and possibility of getting exemption for repayment of loan and interest ranked the 3rd (15.15.\%) (Table X). However, at this stage the interest arose to know the causes of disliking the institutional sources of loan.

Table 10: Reasons for preferring Institutional sources

\begin{tabular}{|l|c|c|}
\hline \multicolumn{1}{|c|}{ Reasons } & Number of respondents & Frequency of percentage * \\
\hline $\begin{array}{l}\text { Prices of fish is not } \\
\text { influenced or exploited }\end{array}$ & 30 & 45.45 \\
\hline $\begin{array}{l}\text { Possibility of getting } \\
\text { Exemption }\end{array}$ & 10 & 15.15 \\
\hline Low rate of interest & 20 & 30.30 \\
\hline Others & 6 & 9.09 \\
\hline
\end{tabular}

* Multiple responses

\section{Reasons for Disliking the Institutional Sources of Loan}

The sample respondents mentioned a number of reasons for disliking the sources of institutional loan. The findings in this regard reveal that among the respondents $56.67 \%$ opined the most important reason is difficult and lengthy loan procedure of institutional sources of loan. The other reasons are 'creation of pressure' ranked the 2nd $(35.34 \%)$; 'demands illegal money' ranked the 3rd $(28.67 \%)$ and needs collateral ranked the 4th $(23 \%)$ (Table XI). It seems that due to illiteracy, non socialization, lacks of linkage with social elites are the other important reasons in disliking the institutional sources of loan. 
Table 11: Reasons for disliking the institutional sources by the respondents

\begin{tabular}{|l|c|c|}
\hline \multicolumn{1}{|c|}{ Reasons } & Number of respondents & Frequency of percentage $*$ \\
\hline Complicated & 25 & 37.88 \\
\hline Create pressure & 10 & 15.15 \\
\hline High interest & 10 & 15.15 \\
\hline Needs collateral & 15 & 22.73 \\
\hline Others & 6 & 9.09 \\
\hline
\end{tabular}

* Multiple responses

\section{CONCLUSION}

The respondent expressed their views regarding their suggestions to overcome problems in getting credit which may be presented in descending order: (i) time relaxation (51.3\%) (ii) no collateral /commission (46.3\%); (iii) low interest rate (35\%); (iv) easy access/ formalities to sources to credit (20\%); (v) government co-operation (12.6\%) and (v) others $(5 \%)$.

In the study areas, during the survey period, it was found that the poor coastal fishermen are very interested in availing different types of credit services. They were found very interested and enthusiastic regarding credit services and their efficient management.

Empowerment of women can help to alleviate poverty and mobilize natural resources. Moreover, arrangement of adequate finance at market rate may contribute significant role in the socio-economic development of coastal women fisher folk in study areas. Again financial support system needs to be dynamic so that concerned women fisher folk can get the benefits of institutional credit facilities. Further, institutions involved in income generating activities and other support services should work in close cooperation among themselves for development of women in the coastal fishing communities of South West Nigeria.

\section{REFERENCES}

Adekanye, T. (1989): "The role of women in Nigeria agriculture". Paper presented at Workshop on farm management in Nigeria held at Akure. $1^{\text {st }}-3^{\text {rd }}$ April $5 p$.

Altieri, M.A. (1993): “Agro ecology, A new research and development paradigm for World Aquaculture". Ecosystems and Environment 27: 37-46

Blowfield, M.E. and Haque N. (1996): Ties Between Marketing and Credit in Coastal Bangladesh - Safety Net or Debt Trap, PHF News, Issue No. 6, Chennai, India

Kabeer, A.A. (2003):"Resources, Agency, Achievements: Reflections on the measurement of Women's empowerment. Development and changes vol. 30, pp 43-63

Kleih, U. (2001): "Fish Distribution from Coastal Communities: Market and Credit Access Issues" Paper presented in workshop at CARITUS auditorium Chittagong, 27-28 March p. 3.

Lightfoot, A.A. (1990): Integration of Aquaculture and Agriculture: a route to Sustainable farming systems NAGA, ICLARM. Q.13 (1): 9-12

Mogbojuri, H.O. (1987): Fisheries activities in Koko village, Delta State, Nigeria. unpublished project submitted for the award of Nigerian Certificate of Education, pp 1-50. Adeyemi College of Education, Ondo

Molynex, M.A. (2002): "Mobilization without emancipation? Women's interest, State and revolution in Nicaragua. Feminist studies, Vol. II No 2 Omotoso, F.O. (2003) Gender roles and effective participation in Artisanal Fisheries in Nigeria- Journal of Women in Natural Resources, 7 (3) pp. 15-32

Omotoso, F.O. (2004) The Role of Rural Women in Sustainable Fisheries Management in Southern Nigeria. Journal of International Fisheries 5 (1) pg.49-56

Saleh, A. (1995): A Profile of the Women Entrepreneurship in Bangladesh, Journal
of
Business
Studies,
Vol.
16(1).
Pp.159-170 